\title{
HUBUNGAN KARAKTERISTIK LAHAN DENGAN PRODUKTIVITAS TBS (Studi Kasus pada PT. Perkebunan Nusantara VIII Cimulang, Bogor)
}

\section{Komarsa Gandasasmita1), Basuki Sumawinata ${ }^{1)}$ dan Sry Nurmala ${ }^{2)}$}

\author{
1) Departemen Ilmu Tanah dan Sumberdaya Lahan, Fakultas Pertanian Institut Pertanian Bogor \\ 2) Alumni Departemen Ilmu Tanah dan Sumberdaya Lahan, Fakultas Pertanian Institut Pertanian Bogor
}

\begin{abstract}
Oil palm (Elaeis guineensis Jacq) is an important crop for Indonesia as one of non fuel export commodities. Development, improvement of quality and productivity of oil palm is influenced by a lot of factors, among others are land characteristics. This research was aimed to know the relationship between oil palm productivity and physical land characteristic including soil, slope and the crop age. The results of this research were expected to be useful to improve oil palm productivity and the oil palm plantation development.

This research was done within the site of PT. Perkebunan Nusantara VIII at Cimulang, Bogor. In this research, analyzing correlation between productivity of blocks that have homogenous land characteristic with physical land characteristic parameter including soil and slope. Block with homogenous land characteristic was block which $75 \%$ or more of it's area had similar characteristics. These blocks were determined by overlying block map, slope map and soil map. The result show that were 20 homogenous blocks out of all the 38 blocks of the site the PT. Perkebunan Nusantara VIII at Cimulang.

Average production was depend on crop age. At study areas, the highest average fresh fruit bunch production obtained from plants 5 years, which was equal to 22.87 tons acre $e^{-1}$ year ${ }^{-1}$ and the lowest average fresh fruit bunch production obtained from plants 3 years, which was equal to 0.66 tons acre ${ }^{-1}$ year ${ }^{-1}$. Based on soil, the highest average fresh fruit bunch production obtained from the SPT 11 (Typic Eutrudox), which was equal to 12.54 tons/acre/year and the lowest average fresh fruit bunch production obtained from SPT 1 (Oxic Dystropept), which was equal to 9.51 tons/acre/year. Based on slope class, the highest average fresh fruit bunch production obtained from block with slope class B (8-15\%), which was equal to 12.54 tons/acre/year, and the lowest average production was equal to 9.98 tons/acre/year from the slope class.
\end{abstract}

Key word : Homogenous land unit, Oil Palm, physical farm

\section{PENDAHULUAN}

Kelapa sawit (Elaeis guineensis Jacq) adalah salah satu tanaman perkebunan yang memiliki masa depan yang cukup cerah. Perkebunan kelapa sawit awalnya berkembang di daerah Sumatera Utara dan Aceh. Namun sekarang telah berkembang di berbagai daerah seperti Riau, Jambi, Sumatera Barat, Sumatera Selatan, Bengkulu, Lampung, Jawa Barat, Kalimantan Barat, Kalimantan Timur, Kalimantan Tengah, Sulawesi, Maluku dan Papua. Pada tahun 2007, Indonesia merupakan negara produsen kelapa sawit terbesar di dunia dengan luas areal 6.78 juta ha dan produksi 17.37 juta ton CPO/ tahun (Dirjenbun, 2008). Walaupun produksi kelapa sawit sudah cukup tinggi, namun besarnya kebutuhan terhadap kelapa sawit mendorong perlunya dilakukan pengelolaan kebun yang tepat, terarah dan efisien untuk meningkatkan kualitas dan produktivitas kelapa sawit sehingga mampu berkompetisi di pasar internasional.

Pengelolaan perkebunan besar antara lain meliputi kegiatan perencanaan, organisasi dan pelaksanaannya dapat dilakukan dengan penerapan teknologi SIG (Sistem Informasi Geografis). Teknologi SIG memiliki kemampuan untuk menangani data bereferensi geografi yang menyajikan objek dalam bentuk dimensi fisik dan memiliki dimensi keruangan. Selain itu, penilaian dan pengolahan data dalam jumlah besar dapat dilaksanakan dengan cepat dan dapat disimpan dalam bentuk data atribut dan data dijital (Prastowo, 1995).

Karena sistem ini mengandalkan komputer, pengelolaan dan pengawasan perkebunan dapat dilakukan dengan mudah sehingga diperoleh pengelolaan yang efisien. Keuntungan utama menggunakan SIG adalah dapat menampilkan informasi yang berupa peta yang dilengkapi dengan data atribut sehingga informasi tersebut dapat digunakan untuk pengambilan keputusan pada waktu cepat.

Suatu peta yang menggambarkan korelasi antara sifat fisik dengan produktivitas komoditas tertentu seperti kelapa sawit akan sangat berguna dalam menetapkan kebijakan dalam rangka pengembangan perkebunan kelapa sawit di Indonesia. Upaya-upaya untuk meningkatkan produktivitas akan lebih efisien bila dilaksanakan pada lahan-lahan yang sesuai atau lahan dengan kondisi fisik yang mendukung.

Pengembangan, peningkatan kualitas dan produktivitas kelapa sawit dipengaruhi oleh banyak faktor antara lain sifat fisik lahan. Pada penelitian ini diamati hubungan antara produktivitas dengan sifat fisik lahan yang meliputi tanah dan lereng serta umur tanaman.

Tujuan dari penelitian ini adalah untuk mengetahui hubungan sifat fisik lahan dengan tingkat produktivitas tanaman kelapa sawit. Hasil penelitian diharapkan akan berguna untuk pengembangan perkebunan kelapa sawit dan dapat digunakan untuk meningkatkan produktivitas kelapa sawit. 


\section{BAHAN DAN METODE}

Bahan-bahan yang digunakan pada penelitian ini adalah Peta Rupa Bumi Indonesia lembar Leuwiliang, Parung dan Bogor skala 1 : 25.000, Peta Administrasi Kebun skala 1 : 20.000, Peta Tanah Perkebunan skala 1 : 10.000, Software Panavue Image Assembler, Software Arc View 3.3, Data Curah Hujan, Data Produksi per blok tahun 2007. Sedangkan alat yang digunakan pada penelitian ini yaitu seperangkat komputer, GPS (Global Positioning System), scanner dan alat tulis. Tahapan-tahapan dalam penelitian disajikan dengan diagram alir pada Gambar 1.

\section{a. Pengecekan Lapang dengan GPS (Global Positioning System)}

Pengecekan lapang dengan menggunakan GPS (Global Positioning System) bertujuan untuk mengetahui koordinat daerah penelitian. Hasil pengecekan lapang disesuaikan dengan peta referensi, sehingga diperoleh koordinat yang tepat.

Pengecekan lapang juga dilakukan pada tahap akhir yang bertujuan untuk verifikasi hasil interpretasi.

\section{b. Penyiaman dan Penggabungan Peta}

Proses penyiaman dengan scanner dilakukan pada seluruh peta. Karena daerah penelitian terdapat pada beberapa lembar peta sehingga setelah peta tersimpan dalam bentuk digital, maka dilakukan penggabungan peta dengan menggunakan software Panavue Image Assembler.

\section{c. Registrasi dan Digitasi}

Peta yang telah digabungkan, kemudian diregistrasi dengan melakukan koreksi geometrik dengan software Arc View 3.3. Koreksi geometrik dilakukan untuk mengaitkan koordinat bumi ke dalam peta yang telah disiam dengan memasukkan nilai koordinat ke dalam suatu titik kontrol dan sistem proyeksinya. Tidak tepatnya penempatan titik kontrol menyebabkan nilai akurasi atau Root Mean Square Error (RMS-Error) semakin besar. Jika RMS-Error semakin kecil $(<1)$ maka akurasinya akan semakin baik dan peta yang terkoreksi akan semakin mendekati posisi yang sebenarnya pada koordinat bumi.

Setelah mempunyai peta terkoreksi maka dilakukan proses digitasi dan pengisian data atribut. Data atribut sering dikategorikan sebagai data non spasial, karena peranannya tidak menunjukkan posisi akan tetapi keterangan mengenai informasi suatu wilayah. Data atribut dapat berupa jenis tanah, kemiringan lereng dan informasi lain yang dibutuhkan.

\section{d. Pembuatan Peta Kelas Lereng (Slope Map)}

Pembuatan peta kelas lereng (slope map) dilakukan dengan menggunakan software Arc View 3.3 dengan menggunakan Extensions 3D Analyst dan Model Builder.

Peta kelas lereng (slope map) diperoleh dari hasil digitasi kontur dari peta topografi dan kemudian dianalisis melalui beberapa tahapan. Tahap pertama adalah mengubah peta kontur menjadi Model Elevasi Digital (Digital Elevation Model/ DEM) dengan metode TIN (Triangulated Irregular Network) dengan memilih Surface Create TIN from features kemudian memasukkan interval kontur (IC) sebagai Height Source sehingga terlihat bentukan tiga dimensi dari topografi daerah penelitian. DEM dapat memberikan gambaran yang lebih jelas mengenai keadaan relief sebenarnya di lapangan (Ardiansyah dan Barus, 2004).

Selanjutnya TIN dikonversi ke dalam bentuk grid yang dikenal dengan istilah rasterisasi, yaitu proses transformasi data spasial yang berbentuk rangkaian titik, garis dan poligon ke bentuk susunan sel yang mempunyai nilai.

Setelah rasterisasi kemudian dilakukan tahap klasifikasi. Pada tahap klasifikasi ini dilakukan pengelompokan kelas kemiringan lereng dengan mengelompokkan nilai kelas lereng berdasarkan nilai yang telah ditetapkan sehingga terbentuk pola tertentu.

Hasil klasifikasi kemudian didigitasi dengan melakukan sedikit generalisasi. Pengelompokan kelas lereng dibuat berdasarkan kriteria kecuraman lereng.

\section{e. Tahap Analisis}

Blok dengan karakteristik lahan homogen diperoleh dari hasil overlay dengan menggunakan fungsi irisan (intersect two themes) antara peta tanah dan peta lereng yang menghasilkan Satuan Peta Tanah (SPT) yang lebih rinci. Satuan Peta Tanah (SPT) kemudian ditumpangtindihkan (overlay) dengan peta blok sehingga menghasilkan blok dengan karakteristik lahan homogen yang memuat informasi-informasi yang dibutuhkan.

Blok dengan karakteristik lahan homogen ini diperoleh dengan ketentuan blok tersebut mempunyai sifat yang sama atau hampir sama dengan luas lebih dari $75 \%$ dari luas blok. Analisis yang dilakukan adalah analisis data atribut dengan tujuan untuk mengetahui

pengaruh dan keterkaitan antara produktivitas dengan parameter yang ditetapkan yaitu sifat fisik lahan yang meliputi kelas kemiringan lereng dan macam tanah. 


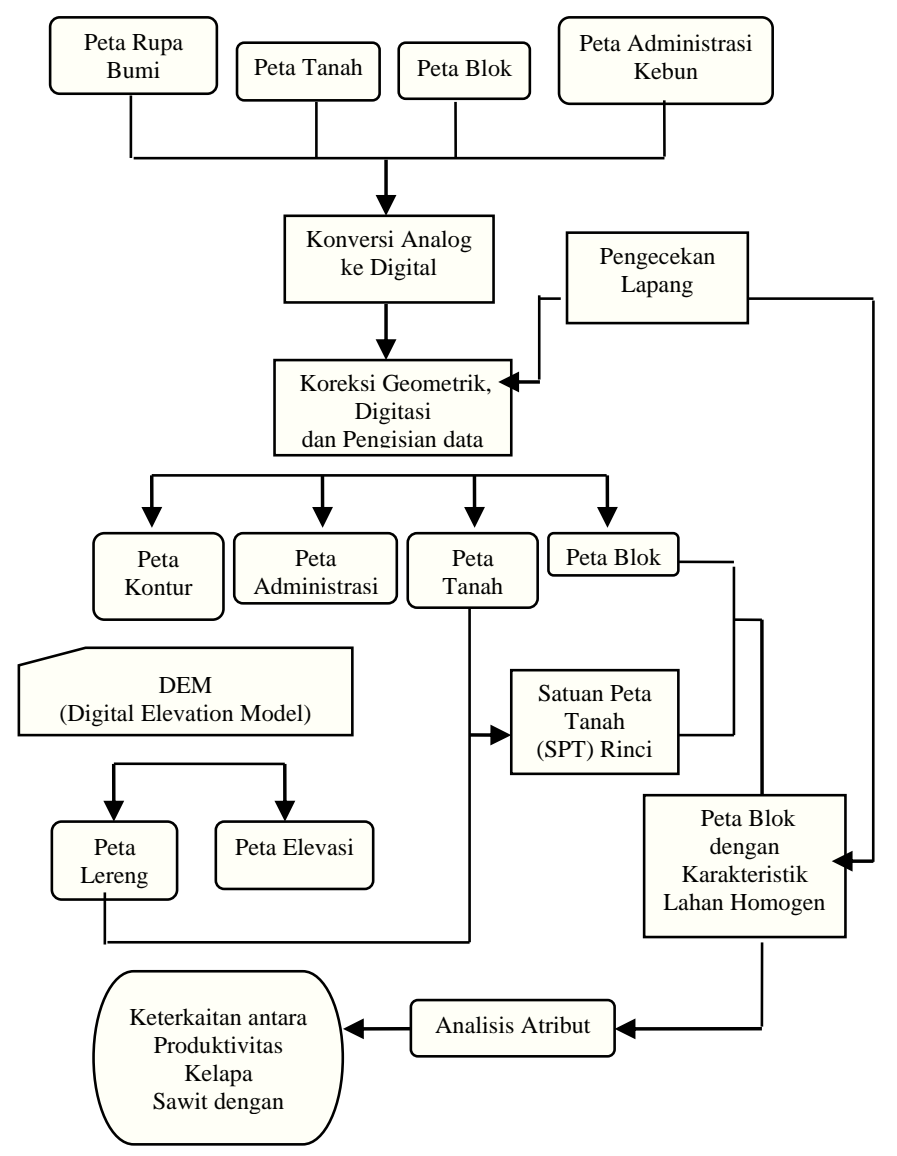

Gambar 1. Diagram Alir Penelitian

\section{HASIL DAN PEMBAHASAN}

\section{Penggunaan SIG dalam Menentukan Blok dengan Karakteristik Lahan Homogen}

Faktor-faktor yang mempengaruhi pertumbuhan dan produksi tanaman di suatu daerah antara lain jenis tanah, lereng, elevasi, curah hujan dan temperatur. Penelitian ini tidak membahas elevasi, curah hujan dan temperatur, karena daerah penelitian yang sempit sehingga pengaruhnya terhadap produksi tidak terlalu nyata. Daerah penelitian berada pada ketinggian <125-250 m dpl sehingga tanaman kelapa sawit dapat tumbuh dengan baik. Demikian juga dengan curah hujan dan temperatur. Curah hujan pada daerah penelitian merata sepanjang tahun dan tipe iklimnya adalah tipe B menurut Schmidt dan Ferguson dengan temperatur rata-rata adalah $24.72^{\circ} \mathrm{C}$.

Blok dengan karakteristik lahan homogen adalah yang $75 \%$ atau lebih dari luasan bloknya memiliki sifat atau karakteristik yang dianggap sama. Pada penelitian, blok-blok yang dianalisis adalah blok-blok yang memiliki karakteristik lahan homogen saja. Hal ini bertujuan untuk memudahkan dalam pengambilan keputusan. Dari 38 blok pada dua afdeling, terdapat 20 blok yang relatif memiliki karakteristik fisik lahan yang homogen. Satuan Lahan Homogen memiliki luasan sebesar 538.70 ha (50.80\%). Blok-blok dengan karakteristik homogen dan penyebarannya dalam bentuk spasial disajikan pada Tabel 1 dan Gambar 2. 


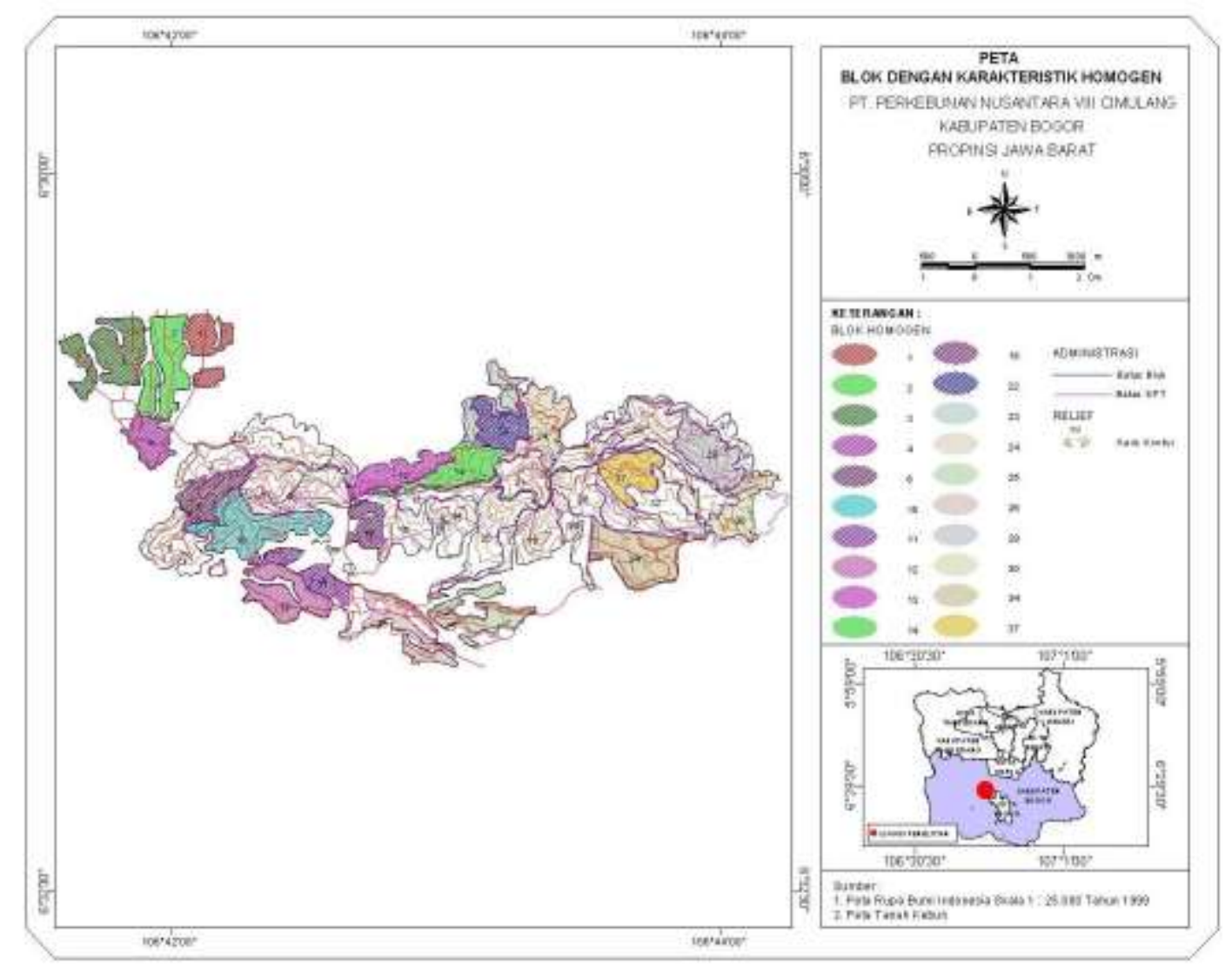

Gambar 2. Peta Blok dengan Karakteristik Lahan Homogen

\section{Hubungan Produktivitas Kelapa Sawit dengan Umur Tanaman}

Selain karakteristik lahan, produktivitas kelapa sawit juga sangat dipengaruhi oleh umur tanaman. Pada umumnya, tanaman kelapa sawit berumur lebih dari 10 tahun dapat berproduksi optimal (Sunarko, 2007) [11].

Saat umur tanaman antara 25-30 tahun, tanaman ini mempunyai produktivitas yang cukup rendah karena umur tanaman yang sudah terlalu tua. Namun pada tanaman muda, walaupun mempunyai buah yang lebih banyak tetapi bobot tandannya masih kecil sehingga beratnya masih kurang dari 10-15 kg. Keadaan seperti ini menyebabkan produktivitas tanaman kelapa sawit rendah. Pengaruh umur tanaman terhadap bobot tandan rata-rata disajikan pada Tabel 2 (Sunarko, 2007) [11].

Tanaman kelapa sawit di daerah penelitian terdiri dari tanaman berumur 5 tahun (tahun tanam 2002), 4 tahun (tahun tanam 2003), 3 tahun (tahun tanam 2004) dan 2 tahun (tahun tanam 2005).

Analisis dilakukan untuk mengetahui pengaruh umur tanaman dengan produktivitas kelapa sawit di daerah penelitian.

Dari hasil penelitian, diperoleh data hubungan umur tanaman dengan produktivitas kelapa sawit yang disajikan pada Tabel 3. Dari tabel diatas, dapat dilihat hubungan umur tanaman dengan produktivitas kelapa sawit yang ditunjukkan dengan grafik pada Gambar 3.

Tabel 2. Bobot Tandan Rata-rata Menurut Umur Tanaman

\begin{tabular}{cc}
\hline Umur (Tahun) & Bobot Tandan $(\mathbf{k g})$ \\
\hline 4 & $4-5$ \\
5 & $6-7$ \\
$6-7$ & $8-9$ \\
$8-9$ & $10-11$ \\
10 & $12-15$ \\
$11-13$ & 17 \\
$14-15$ & 18 \\
$16-17$ & 20 \\
$18-19$ & 22 \\
$20-21$ & 25 \\
$22-23$ & 22 \\
$24-25$ & 20 \\
\hline
\end{tabular}

Sumber: PTPN VII (1993) 
Tabel 3. Hubungan Produktivitas Kelapa Sawit dengan Umur tanaman

\begin{tabular}{|c|c|c|c|c|c|}
\hline $\begin{array}{c}\text { Umur Tanam } \\
\text { (Tahun) }\end{array}$ & Periode & $\begin{array}{l}\text { Tahun } \\
\text { Tanam }\end{array}$ & Blok & $\begin{array}{c}\left.\begin{array}{c}\text { Produksi } \\
(\text { ton ha }\end{array} \text { thn }^{-1}\right) \\
\end{array}$ & $\begin{array}{c}\text { Produksi Rata-rata } \\
\left(\text { ton } \mathrm{ha}^{-1} \text { thn }^{-1}\right)\end{array}$ \\
\hline \multirow[t]{4}{*}{5} & \multirow[t]{4}{*}{ TM 3} & \multirow[t]{2}{*}{2002} & 1 & 22.86 & 22.87 \\
\hline & & & $\begin{array}{l}2 \\
4\end{array}$ & $\begin{array}{l}22.00 \\
9.51\end{array}$ & \multirow{7}{*}{10.50} \\
\hline & & & 11 & 8.83 & \\
\hline & & & 12 & 11.59 & \\
\hline \multirow{5}{*}{4} & \multirow{5}{*}{ TM 2} & 2003 & 34 & 12.54 & \\
\hline & & & 18 & 10.93 & \\
\hline & & & 6 & 8.93 & \\
\hline & & & 10 & 11.16 & \\
\hline & & & 13 & 0.92 & \multirow{4}{*}{0.66} \\
\hline \multirow{3}{*}{3} & \multirow{3}{*}{ TM 1} & & 14 & 0.80 & \\
\hline & & 2004 & 29 & 0.02 & \\
\hline & & & 30 & 0.88 & \\
\hline
\end{tabular}

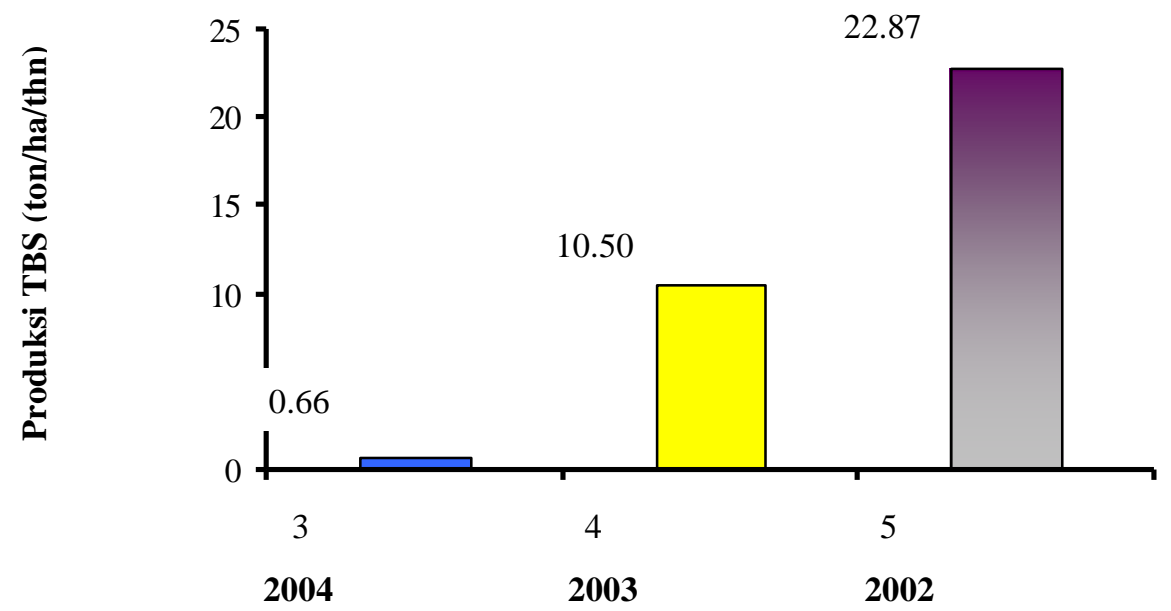

Umur Tanam (tahun) dan Tahun Tanam

Gambar 3. Grafik Hubungan Produktivitas dengan Umur Tanam

Dari tabel dan grafik, dapat dilihat bahwa produksi rata-rata TBS tertinggi di daerah penelitian terdapat pada kelapa sawit dengan umur tanam 5 tahun yaitu sebesar 22.87 ton/ha/thn, sedangkan produksi rata-rata TBS terendah terdapat pada tanaman berumur 3 tahun yaitu sebesar 0.66 ton/ha/thn. Tanaman berumur 2 tahun masih merupakan Tanaman Belum Menghasilkan (TBM). Dalam keadaan normal, perubahan TBM ke TM terjadi pada tahun ketiga sesudah tanaman ditanam, misalnya tanaman ditanam tahun 2004, dipanen 2007 (Pahan, 2006) [7].

Di bawah ini adalah tabel acuan produktivitas tanaman kelapa sawit menghasilkan berdasarkan umur tanaman.

Tabel 4. Keragaan Produktivitas Tanaman Kelapa Sawit Menghasilkan Menurut Umur Tanaman

\begin{tabular}{|c|c|c|c|c|c|}
\hline \multirow{2}{*}{ Umur Tanam (tahun) } & \multirow{2}{*}{ Periode } & \multicolumn{3}{|c|}{ Potensi TBS (ton ha' ${ }^{-1}$ ) } & \multirow{2}{*}{$\begin{array}{l}\text { Realisasi Produktivitas TBS } \\
\text { (ton ha-1 } \text { thn }^{-1} \text { ) }\end{array}$} \\
\hline & & S-1 & S-2 & S-3 & \\
\hline 3 & TM 1 & 9.00 & 7.30 & 6.20 & 0.66 \\
\hline 4 & TM 2 & 15.00 & 13.50 & 12.00 & 10.50 \\
\hline 5 & TM 3 & 18.00 & 16.00 & 14.50 & 22.87 \\
\hline 6 & - & 21.10 & 18.50 & 17.00 & - \\
\hline
\end{tabular}

Sumber : Pusat Penelitian Kelapa Sawit, 2009

Berdasarkan tabel diatas, maka dapat dibandingkan produksi rata-rata TBS di daerah penelitian dengan standar produksi rata-rata TBS berdasarkan umur tanaman menurut Pusat Penelitian Kelapa Sawit (PPKS, 2009).

Dari hasil perbandingan umur tanaman yang sama, produksi rata-rata TBS di daerah penelitian masih dibawah standar hasil menurut PPKS, karena produksi rata-rata pada tanaman 4 tahun masih termasuk kedalam kelas S-3 (Sesuai Marginal) dan tanaman berumur 3 tahun termasuk ke dalam kelas N. Hanya tanaman berumur 5 tahun memiliki produksi rata-rata TBS yang termasuk kelas S-1. 


\section{Hubungan Produktivitas Kelapa Sawit dengan Macam Tanah}

Macam tanah yang berbeda-beda mengakibatkan pengaruh yang berbeda pula terhadap pertumbuhan dan produktivitas tanaman.

Blok-blok yang terwakili dengan macam tanah homogen yaitu SPT 1 (Oksik Dystropept), SPT 10 (Akuik
Humitropept), SPT 11 (Typic Eutrudox), SPT 4 (Typic Haplohumult), SPT 17 (Ortoksik Palehumult), SPT 23 (Humoksik Tropohumult) dan SPT 10 (Typic Tropohumult). Hubungan produktivitas dengan macam tanah disajikan pada Tabel 5 dan Gambar 5.

Tabel 5. Hubungan Produktivitas Kelapa Sawit dengan Macam Tanah

\begin{tabular}{|c|c|c|c|c|c|c|c|}
\hline $\begin{array}{c}\text { Umur } \\
\text { Tanam } \\
\text { (tahun) }\end{array}$ & Periode & $\begin{array}{l}\text { Tahun } \\
\text { Tanam }\end{array}$ & SPT & Blok & Macam Tanah & $\begin{array}{l}\text { Produksi TBS } \\
\left(\text { ton ha } \mathbf{h}^{-1} \text { thn }^{-1}\right)\end{array}$ & $\begin{array}{l}\text { Produksi Rata-rata } \\
\quad\left(\text { ton ha } \mathbf{h a}^{-1} \text { thn }^{-1}\right)\end{array}$ \\
\hline \multirow[t]{4}{*}{5} & \multirow[t]{4}{*}{ TM 1} & \multirow[t]{4}{*}{2002} & $\begin{array}{l}1 \\
1\end{array}$ & $\begin{array}{l}1 \\
2\end{array}$ & $\begin{array}{l}\text { Oksik Dystropept } \\
\text { Oksik Dystropept }\end{array}$ & $\begin{array}{c}22.86 \\
22.8\end{array}$ & 22.87 \\
\hline & & & 1 & 4 & Oksik Dystropept & 9.51 & 9.51 \\
\hline & & & 8 & 6 & Typic Tropohumult & 8.93 & \\
\hline & & & 8 & 10 & Typic Tropohumult & 11.16 & 10.05 \\
\hline \multirow{4}{*}{4} & \multirow{4}{*}{ TM 2} & \multirow{4}{*}{2003} & 10 & 12 & Akuik Humitropept & 11.59 & 10.21 \\
\hline & & & 23 & 18 & Humoksik Tropohumult & 10.93 & 10.93 \\
\hline & & & 11 & 34 & Typic Eutrudox & 12.54 & 12.54 \\
\hline & & & 4 & 13 & Typic Haplohumult & 0.92 & \multirow{3}{*}{0.58} \\
\hline \multirow{3}{*}{3} & \multirow{3}{*}{ TM 3} & \multirow{3}{*}{2004} & 4 & 14 & Typic Haplohumult & 0.8 & \\
\hline & & & 4 & 29 & Typic Haplohumult & 0.02 & \\
\hline & & & 17 & 30 & Ortoksik Palehumult & 0.88 & 0.88 \\
\hline
\end{tabular}

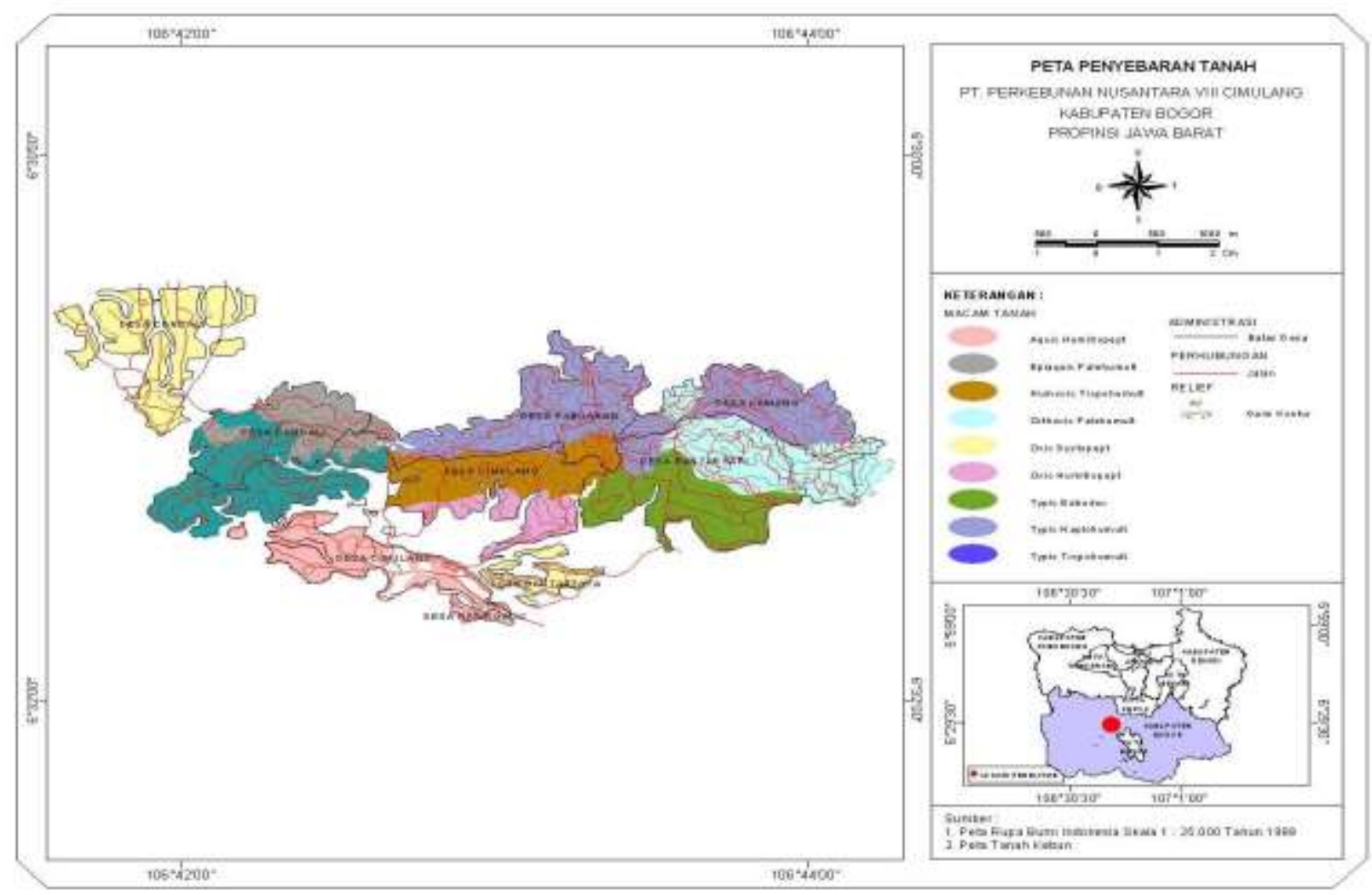

Gambar 4. Peta Penyebaran Tanah Daerah Penelitian 


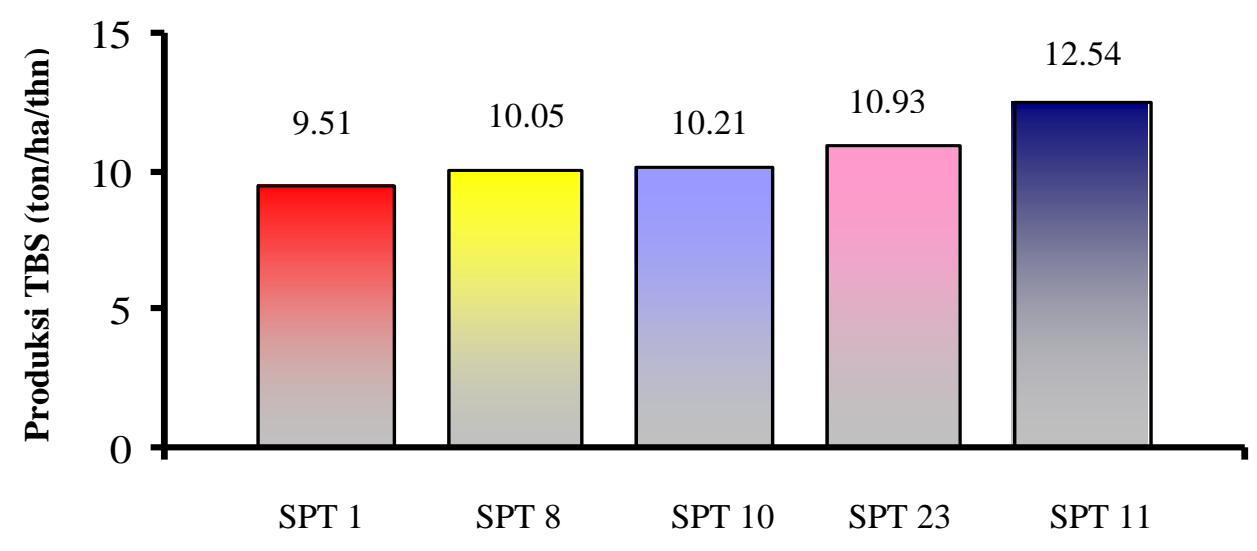

Satuan Peta Tanah (SPT)

Gambar 5. Grafik Produksi TBS pada Tahun Tanam 2003

Dari data, dapat dilihat bahwa produksi TBS rata-rata tertinggi pada tahun tanam 2003 terdapat pada SPT 11 (Typic Eutrudox) yaitu 12.5 ton/ha/thn, sedangkan produksi TBS terendah terdapat pada SPT 1 (Oksik Dystropept) yaitu $9.51 \mathrm{ton} / \mathrm{ha} / \mathrm{thn}$. Tinggi rendahnya produksi dapat disebabkan oleh beberapa faktor. Tingginya produksi pada SPT 11 (Typic Eutrudox) disebabkan karena tanah-tanah Eutrudox mempunyai kejenuhan basa lebih dari $35 \%$ dan mempunyai porositas yang baik, sedangkan rendahnya produksi pada SPT 1 (Oksik Dystropept) dapat disebabkan karena kejenuhan basanya yang kurang dari 24\%. Hal seperti ini dapat mempengaruhi pertumbuhan dan produktivitas tanaman tersebut. Macam tanah cenderungtidak berpengaruh nyata terhadap produktivitas kelapa sawit, namun $\mathrm{pH}$ memiliki kecenderungan pengaruh terhadap produktivitas kelapa sawit. Produksi tanaman dengan tahun tanam 2002 dan 2004 tidak dibahas lebih lanjut karena keterbatasan data pembanding antar SPT sehingga perbedaan produksi tidak terlalu jelas.

\section{Hubungan Produktivitas Kelapa Sawit dengan Kemiringan Lereng}

Pada umumnya, semakin curam lereng maka produksi suatu tanaman akan semakin rendah (Arsyad, 2000). Kemiringan lereng di daerah penelitian dibagi menjadi 4 kelas lereng yaitu kelas A (0-8\%), kelas B (8$15 \%)$, kelas C (15-25\%) dan kelas D (25-40\%). Tetapi yang termasuk kedalam kelas lereng yang homogen hanya 3 kelas lereng yaitu kelas lereng A, B, dan C. Menurut Renlia (2003), produksi pada kemiringan lereng 0-3\% lebih tinggi dibandingkan pada kemiringan lereng 3-8\%. Hal ini menunjukkan kemiringan lereng mempengaruhi efektivitas input yang diberikan. Dengan dilakukannya pengelolaan berupa pemupukan dan pemeliharaan kebun, lahan dengan kemiringan lereng 0-3\% dapat menyediakan unsur hara yang mencukupi untuk tanaman tanpa terjadinya proses pengangkutan karena erosi. Data produksi rata-rata berdasarkan kemiringan lereng disajikan pada Tabel 6 dan Gambar 7. 


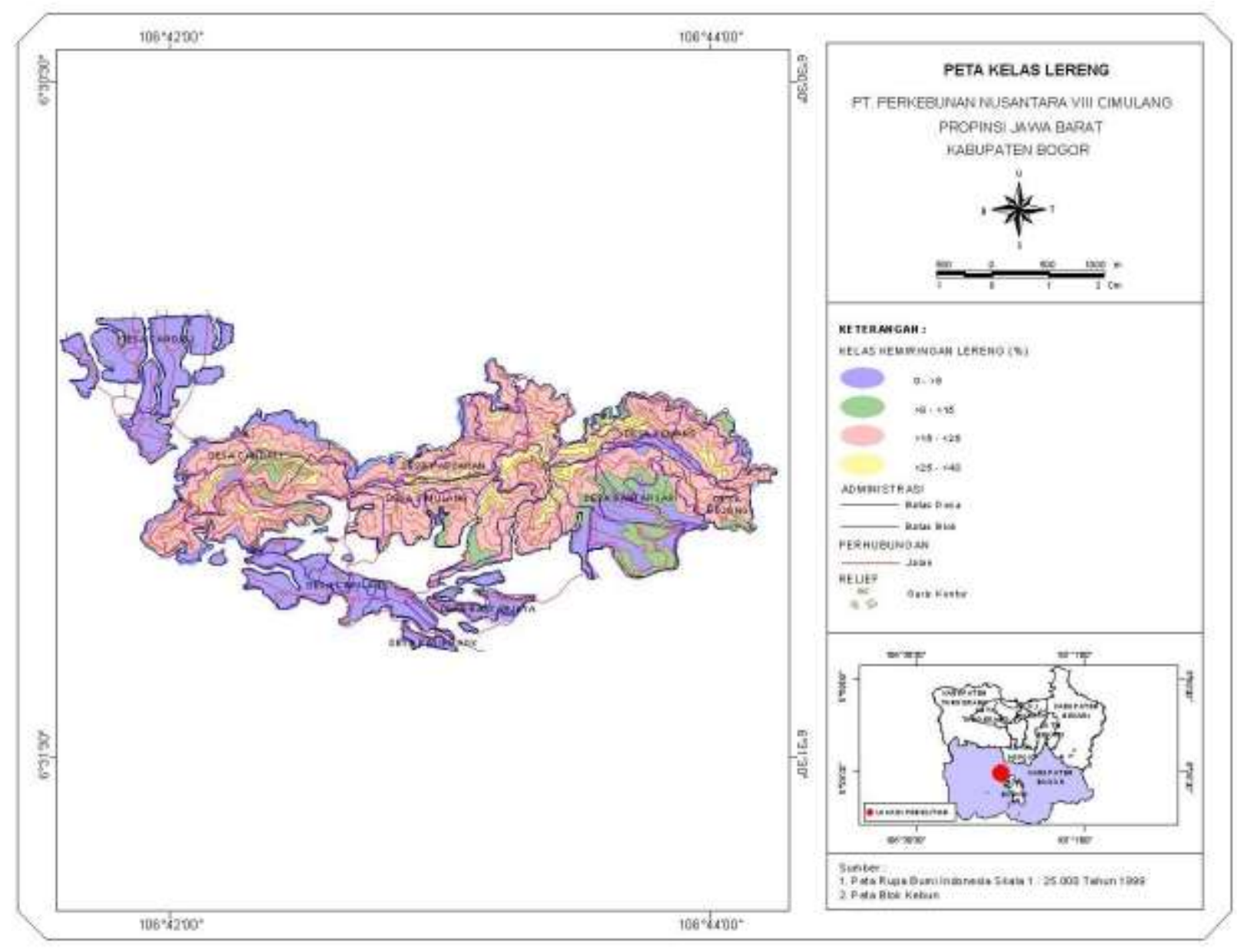

Gambar 6. Peta Kelas Lereng Daerah Penelitian

Tabel 6. Hubungan Produktivitas Kelapa Sawit dengan Kemiringan Lereng

\begin{tabular}{|c|c|c|c|c|c|c|c|}
\hline $\begin{array}{c}\text { Umur Tanam } \\
\text { (tahun) }\end{array}$ & Periode & $\begin{array}{l}\text { Tahun } \\
\text { Tanam }\end{array}$ & Blok & Lereng & Macam Tanah & $\begin{array}{l}\text { Produksi TBS } \\
\left(\text { ton }^{-1} \mathrm{a}^{-1} \mathrm{th}^{-1}\right)\end{array}$ & $\begin{array}{l}\text { Produksi Rata-rata } \\
\left(\text { ton }^{-1} \mathrm{~h}^{-1} \mathrm{thn}^{-1}\right)\end{array}$ \\
\hline \multirow{5}{*}{5} & \multirow{5}{*}{ TM 3} & \multirow{5}{*}{2002} & 1 & $0-8$ & Oksik Dystropept & 22.86 & \multirow{2}{*}{22.87} \\
\hline & & & 2 & $0-8$ & Oksik Dystropept & 22.8 & \\
\hline & & & 4 & $0-8$ & Oksik Dystropept & 9.51 & \\
\hline & & & 11 & $0-8$ & Akuik Humitropept & 8.83 & 9.98 \\
\hline & & & 12 & $0-8$ & Akuik Humitropept & 11.59 & \\
\hline \multirow[t]{5}{*}{4} & \multirow{5}{*}{ TM 2} & \multirow{5}{*}{2003} & 34 & $8-15$ & Typic Eutrudox & 12.54 & \multirow{2}{*}{12.54} \\
\hline & & & 18 & $15-25$ & Humoksik Tropohumult & 10.93 & \\
\hline & & & 6 & $15-25$ & Typic Tropohumult & 8.93 & \multirow[t]{3}{*}{10.34} \\
\hline & & & 10 & $15-25$ & Typic Tropohumult & 11.16 & \\
\hline & & & 13 & $15-25$ & Typic Haplohumult & 0.92 & \\
\hline \multirow{3}{*}{3} & \multirow{3}{*}{ TM 1} & \multirow{3}{*}{2004} & 14 & $15-25$ & Typic Haplohumult & 0.8 & \multirow{3}{*}{0.66} \\
\hline & & & 29 & $15-25$ & Typic Haplohumult & 0.02 & \\
\hline & & & 30 & $15-25$ & Ortoksik Palehumult & 0.88 & \\
\hline
\end{tabular}




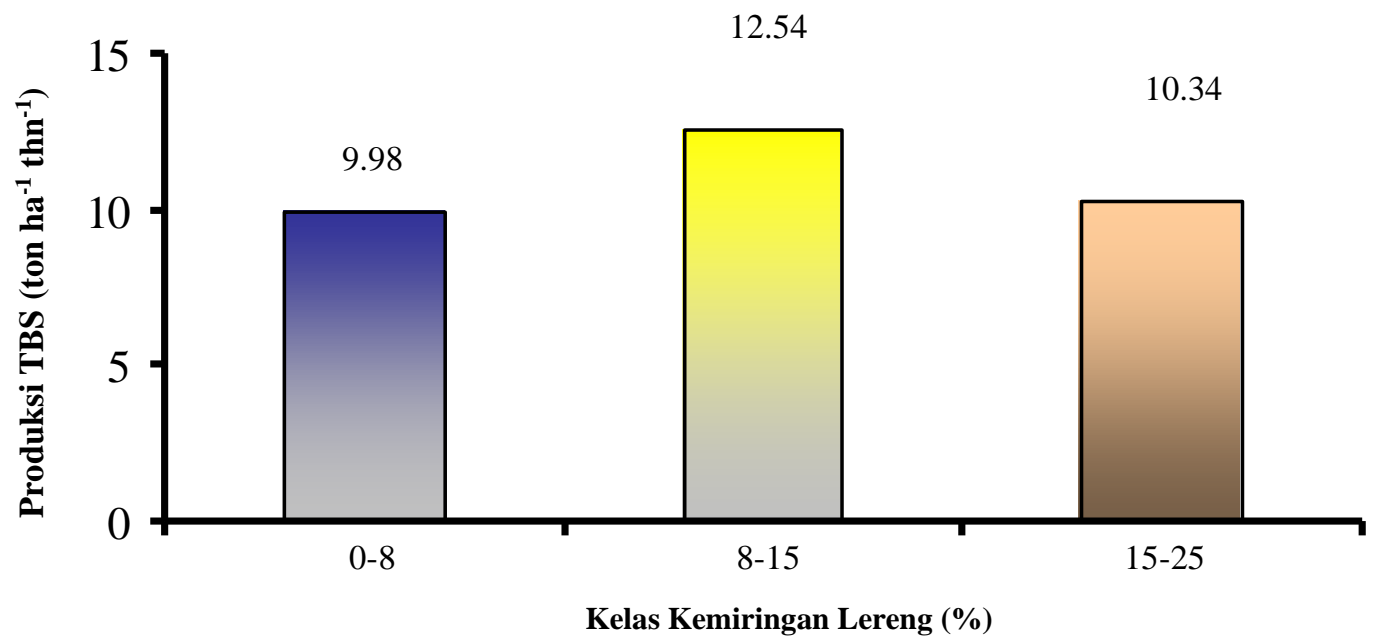

Gambar \%. Gratık Hubungan Produktıvitas dengan Kemırıngan Lereng

Grafik diatas merupakan grafik produksi rata-rata TBS berdasarkan kemiringan lereng dengan tahun tanam 2003. Tahun tanam 2002 dan 2004 tidak disajikan dalam grafik karena data produksi pembanding antar kelas kemiringan lereng tidak ada. Produksi keduanya hanya terdapat pada satu kelas kemiringan lereng yaitu kelas A (0-8\%) pada tahun tanam 2002 dan kelas kemiringan lereng C (15-25\%) pada tahun 2004.

Berdasarkan grafik, produksi kelapa sawit terendah pada daerah penelitian terdapat pada kelas lereng A $(0-8 \%)$ yaitu 9.98 ton/ha/thn dibandingkan pada kelas lereng B (8$15 \%$ ) sebesar 12.54 ton/ha/thn dan kelas lereng C (15$25 \%$ ) sebesar 10.34 ton/ha/thn.

Seperti telah disebutkan diatas bahwa pada umumnya produksi akan rendah pada lereng yang lebih curam. Hal ini dapat disebabkan karena hilangnya unsur hara oleh erosi yang umumnya terdapat pada lereng curam (Arsyad, 2000). Namun, di daerah penelitian kelas lereng A (0-8\%) memiliki produksi terendah dibandingkan kelas lereng $\mathrm{B}$ dan kelas lereng C. Hal ini disebabkan karena pada sebagian daerah ini (SPT 10 blok 11 dan 12) dijumpai faktor penghambat pertumbuhan yaitu drainase yang buruk, sehingga dapat mengakibatkan rendahnya produksi pada kelas lereng A (0-8\%). Drainase yang buruk umumnya tidak disukai tanaman kelapa sawit karena dapat menghambat kelancaran dalam proses penyerapan unsur hara.

Produksi TBS pada kelas lereng B (8-15\%) lebih tinggi daripada kelas lereng $\mathrm{C}(15-25 \%)$ disebabkan karena efektivitas pengelolaan kebun lebih tinggi. Kemiringan lereng yang lebih landai lebih memudahkan proses pemeliharaan kebun dan pemupukan. Kondisi seperti ini dapat mempengaruhi unsur hara yang ada di dalam tanah yang berakibat pada produktivitas tanaman kelapa sawit di lahan ini.

\section{KESIMPULAN DAN SARAN}

Dari 38 blok yang terdapat di PT. Perkebunan Nusantara VIII Cimulang, terdapat 20 blok yang merupakan Satuan Lahan Homogen (SLH). Total luas
Satuan Lahan Homogen (SLH) adalah 538.20 ha atau $50.80 \%$ dari total luas areal kelapa sawit.

Umur tanaman mempengaruhi produktivitas kelapa sawit. Di daerah penelitian, produksi rata-rata TBS cukup tinggi terdapat pada kelapa sawit berumur 5 tahun yaitu sebesar 22.87 ton/ha/thn, sedangkan produksi terendah terdapat pada kelapa sawit dengan umur tanam 3 tahun yaitu sebesar 0.66 ton/ha/thn.

Macam tanah cenderung tidak berpengaruh nyata terhadap produktivitas kelapa sawit. Hal ini disebabkan karena tanah-tanah di daerah penelitian memiliki sifat fisik tanah yang cukup baik untuk tanaman kelapa sawit.

Kelas kemiringan lereng memiliki hubungan dengan tingkat produktivitas tanaman kelapa sawit. Berdasarkan kelas kemiringan lereng, tanaman dengan tahun tanam 2003 mempunyai produksi rata-rata TBS tertinggi pada kelas lereng B (8-15\%) yaitu sebesar 12.54 ton/ha/thn. Produktivitas TBS menurun pada lereng yang lebih curam (15-25\%), Sedangkan produksi rata-rata TBS terendah terdapat pada lereng yang lebih rendah yaitu kelas lereng A $(0-8 \%)$ yaitu sebesar 9.98 ton/ha/thn. Hal ini disebabkan karena pada sebagian kelas lereng A (0-8\%) terdapat faktor penghambat drainase yang buruk.

\section{DAFTAR PUSTAKA}

Ardiansyah, dan B. Barus. 2004. Model Elevasi Digital Untuk Analisis Landform Vulkanik dan Hubungannya dengan Satuan Tanah di Cisarua Bogor. Jurnal Tanah dan Iklim. No. 22.

Arsyad, S. 2000. Konservasi Tanah dan Air. Bogor : Institut Pertanian Bogor, Fakultas Pertanian, Program Studi Ilmu Tanah.

Barus, B dan U.S. Wiradisastra. 1997. Sistem Informasi Geografis. Bogor : Institut Pertanian Bogor, Fakultas Pertanian, Program Studi Ilmu Tanah.

Direktorat Jenderal Perkebunan Departemen Pertanian. 2006. Komitmen Pemerintah Membangun Perkebunan Kelapa Sawit Berkelanjutan. 
http://www.ditjenbun.deptan.go.id. [15 agustus 2008].

Hadjowigeno.S dan Widiatmaka. 1999. Kesesuaian Lahan dan Perencanaan Tata Guna lahan. Bogor : Institut pertanian Bogor, Fakultas Pertanian, Program Studi Ilmu Tanah.

Harahap, E. 1999. Perkembangan Akar Tanaman Kelapa Sawit pada Tanah Terdegradasi di Sosa Tapanuli Selatan. Disertasi. Bogor : Institut Pertanian Bogor, Fakultas Pertanian, Program Studi Ilmu Tanah.

Pahan, I. 2006. Panduan Lengkap Kelapa Sawit. Manajemen Agribisnis dari Hulu hingga Hilir. Jakarta : PT. Penebar Swadaya.

Prastowo, S.1995. Aplikasi Informasi Geografis Untuk Pengelolaan Perkebunan Besar. Pertemuan Ilmiah Tahunan Masyarakat Penginderaan Jauh (MAPIN) tanggal 5-6 Desember 1995. Surabaya.
Pusat Penelitian Kelapa Sawit. 2009. Rekomendasi Pemupukan Tanaman Kelapa Sawit Menghasilkan Unit Usaha Durian Luncuk PT. Perkebunan Nusantara VI.

Renlia, I. 2003. Evaluasi Lahan Tanaman Kelapa Sawit (Elaeis guineensis Jacq.) Berdasarkan Pada Produksi Tandan Buah Segar (TBS) dengan Bantuan Sistem Informasi Geografis (SIG). Skripsi. Bogor : Institut Pertanian Bogor, fakultas Pertanian, Program Studi Ilmu Tanah.

Sunarko. 2007. Petunjuk Praktis Budidaya \& Pengolahan Kelapa Sawit. Jakarta : PT. AgroMedia Pustaka.

Soil Survey Staff. 1975. Soil Taxonomy. System of Soil Classification for Making and Interpreting Soil Survey. SCS-USDA, Handb.436. US. Gort. Printing Office, Washington D.C. 